Yol.2 2Nn. I لanuari 2019

ISSN 2614-2775

e-ISSN 2621-8143

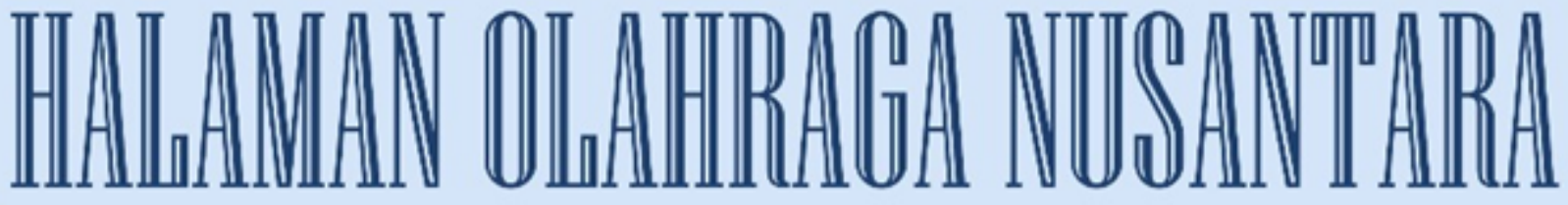

Surnal @lmu Xeolahragaan

Diterbitkan Oleh:

Program Studi Pendidikan Olahraga

Fakultas Keguruan dan Ilmu Pendidikan

Universitas PGRI Palembang

Jurnal

Volume Nomor Halaman Palembang ISSN/e-ISSN

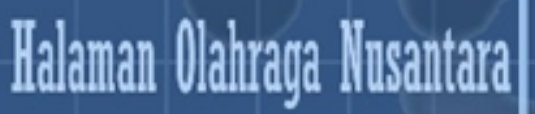

\begin{tabular}{l|l|l|l}
2 & 1 & $1-96$ & 2019
\end{tabular}




\section{Halaman Olahraga Nusantara}

Jurnal Ilmu Keolahragaan

Volume 2, Nomor 1, Januari 2019

Pelindung/Penasehat

Dr. H. Bukman Lian, M. M., M. Si.

Penanggung Jawab

Dr. Dessy Wardiah, M. Pd.

Ketua Dewan Redaksi

Farizal Imansyah, M. Pd.

Wakil Ketua Dewan Redaksi

Ilham Arvan Junaidi, M. Pd.

Sekretaris

Bayu Iswana, M. Pd.

Penyunting Pelaksana

Rafel Orlando, M. Pd.

Ardo Okilanda, M. Pd.

Daryono, M. Pd.

\section{Mitra Bestari}

Prof. Dr. A. Sofyan Hanif, M. Pd (Universitas Negeri Jakarta)

Dr. Sukirno (Universitas Sriwijaya)

Dr. Ronni Yenes, M. Pd (Universitas Negeri Padang)

Dr. Benny, M. Pd. (Universitas Negeri Makasar)

Dr. Putri Cicilia Kristina, M. Pd (Universitas PGRI Palembang)

\section{Tata Usaha}

M. Taheri Akbar, M. Pd.

Widya Handayani, S. Pd., M. Si.

Setting:

Dede Dwiansyah Putra, M. Pd.

Alamat Redaksi:

Prodi Pendidkan Olahraga Fakultas Keguruan Ilmu dan Pendidikan Universitas PGRI Palembang

Jl. Jendral A. Yani Lorong Gotong Royong 9/10 Ulu Palembang

Telp. 0711-510043, Fax. 0711-514782

e-mail jurnal: jurnalhonupgripalembang@gmail.com

e-mail : ardo.oku@univpgri-palembang.ac.id

website: univpgri-palembang.ac.id 
Halaman Olahraga Nusantara (Jurnal Ilmu Keolahragaan)

P-ISSN 2614-2775

Volume 2, No. 1, Januari 2019

E-ISSN 2621-8143

\section{DAFTAR ISI}

Hasil Penelitian

Halaman

Pengaruh Metode Rangkaian Bermain Terhadap Keterampilan Dasar Olahraga Panahan Siswa Ektrakulikuler Sit (Sekolah Islam Terpadu) Auladi Palembang

- Arisman

Penerapan Metode Bermain Dalam Meningkatkan Hasil Belajar Guling Depan (Forward Roll)

- Ruslan, M. Samsul Huda

Survei Tingkat Kesegaran Jasmani pada Peserta Ekstrakulikuler Sepakbola Di Sma Negeri 2 Oku

- Daryono

Kontribusi Daya Ledak Tungkai dan Keseimbangan Terhadap Kemampuan Lompat Jauh Murid Sd Negeri 139 Sinjai

- Adam Mappaompo

Survei Tingkat Kebugaran Jasmani Mahasiswa Pendidikan Olahraga Angkatan 2017 Stkip Pgri Bangkalan

- Heni Yuli Handayani .

Profil Delayed Onset Muscle Soreness (Doms) pada Mahasiswa Fik Unp Setelah Latihan Fisik

- Heru Syarli Lesmana

Perbedaan Pengaruh Latihan Menggunakan Karet dengan Menggunakan Dumbbell $1 \mathrm{Kg}$ Terhadap Kecepatan Pukulan Oi Tsuki

Chudan pada Atlet Karate Putra Perguruan Wadokai Dojo Sma Negeri 11 Medan Tahun 2017

- Pangondian Hotliber Purba $60-71$

Tinjauan Kondisi Fisik Atlet Sepakbola Kabupaten Kerinci Dalam

Rangka Persiapan Mengikuti Porprov Xxii Bungo Tebo 2018

- Palmizal, Wawan Junresti Daya, dan Sri Murniati

Aktivitas Jasmani dan Persepsi Gerak Anak Usia Dini

- Dian Pujianto 
Peningkatan Keterampilan Bermain Bolabasket Mahasiswa Melalui Latihan Aktifitas Maze Perkuliahan Permainan Bolabasket

- Ilham Arvan Junaidi dan Rury Rizhardy $88-96$ 


\title{
PERBEDAAN PENGARUH LATIHAN MENGGUNAKAN KARET \\ DENGAN MENGGUNAKAN DUMBBELL 1 KG TERHADAP \\ KECEPATAN PUKULAN OI TSUKI CHUDAN PADA \\ ATLET KARATE PUTRA PERGURUAN WADOKAI \\ DOJO SMA NEGERI 11 MEDAN TAHUN 2017
}

\author{
Oleh: Pangondian Hotliber Purba \\ (Dosen Universitas Negeri Medan)
}

\begin{abstract}
Abstrak
Penelitian bertujuan untuk mengetahui perbedaan pengaruh latihan karet dengan latihan menggunakan Dumbbell $1 \mathrm{~kg}$ terhadap kecepatan pukulan Oi tsuki Chudan pada atlet karate putra perguruan Wadokai Dojo SMA Negeri 11 Medan Tahun 2017. Metode penelitian ini adalah metode eksperimen. Latihan Menggunakan Karet secara signifikan lebih besar pengaruhnya di bandingkan latihan Dumbbell $1 \mathrm{Kg}$ terhadap pukulan Oi-tsuki Chudan pada atlet karateka putra perguruan Wadokai dojo SMA Negeri 11 Medan Tahun 2017. Berdasarkan analisis uji hipotesis 1 diperoleh bahwat ${ }_{\text {hitung }}>t_{\text {tabel }}(5,21>1,70)$, maka hipotesis $H_{o}$ ditolak dan $H_{a}$ diterima. Ada pengaruh latihan menggunakan Karet terhadap kecepatan pukulan Oi-tsuki chudan pada atlet karate putra Perguruan Wadokai dojo SMA Negeri 11 Medan Tahun 2017. Berdasarkan analisis uji hipotesis 2 diperoleh bahwat $t_{\text {hitung }}>t_{\text {tabel }}$ (4,51>1,70), maka hipotesis $H_{o}$ ditolak dan $H_{a}$ diterima.Ada pengaruh latihan menggunakan Dumbbell $1 \mathrm{~kg}$ terhadap kecepatan pukulan Oi-tsuki chudan pada atlet karate putra Perguruan Wadokai dojo SMA Negeri 11 Medan Tahun 2017. Berdasarkan analisis uji hipotesis 3, dapat disimpulkan bahwa nilai rata-rata Post-test untuk kelompok latihan karet lebih tinggi daripada kelompok latihan Dumbbell $1 \mathrm{~kg}$. Kriteria pengujian untuk data Post-test diperoleh thitung $>t_{\text {tabel }}$ yaitu 1,90> 1,70 artinya Ho ditolak dan $\mathrm{Ha}$ diterima maka kemampuan akhir atlet kelompok karet lebih cepat dibandingkan kemampuan akhir atlet kelompok Dumbbell $1 \mathrm{~kg}$, sehingga dapat disimpulkan bahawa latihan karet lebih besar pengaruhnya dari pada latihan menggunakan Dumbbell $1 \mathrm{~kg}$ terhadap kecepatan pukulan Oi tsuki Chudan pada atlet karate putra Perguruan Wadokai Dojo SMA Negeri 11 Medan Tahun 2017.
\end{abstract}

Kata Kunci : Karet, Dumbbell, Kecepatan Oi Tsuki Chudan

\section{THE DIFFERENCE OF EXERCISE EFFECT BY USING 1 KG RUBBER DUMBBELL ON OI TSUKI CHUDAN SPEED AT KARATE ATHLET WADOKAI DOJO STATE 11 HIGH SCHOOL MEDAN 2017}

\footnotetext{
Abstract

The study aims to determine the differences in the effect of rubber training on exercise using $1 \mathrm{~kg}$ Dumbbell on the speed of stroke Oi tsuki Chudan in male karate athletes at Wadokai Dojo 11 Medan High School in 2017. The
} 
method of this research is the experimental method. Rubber Using Exercises significantly had a greater effect compared to $1 \mathrm{Kg}$ Dumbbell exercises against Oi-tsuki Chudan's blows in male karateka athletes in Wadokai dojo Medan Medan High School in 2017. Based on the analysis of hypothesis 1 test, it was found that $>(5,21>1,70)$, then the hypothesis Ho is rejected and Ha is accepted. There is the effect of using Rubber training on the speed of blows Oi-tsuki chudan on male karate athletes at Wadokai dojo College Medan 11 High School in 2017. Based on the analysis of hypothesis 2 test, it was found that> (4.51> 1.70), the hypothesis Ho was rejected and Ha received. There is an effect of exercise using 1 $\mathrm{kg}$ Dumbbell on the speed of blows Oi-tsuki chudan in male karate athletes at Wadokai dojo College Medan 11 High School in 2017. Based on the analysis of hypothesis 3 testing, it can be concluded that the average post-test for rubber training groups higher than the $1 \mathrm{~kg}$ Dumbbell exercise group. Test criteria for Post-test data were obtained tcount t table that is 1.901 .70 means that Ho is rejected and $\mathrm{Ha}$ is accepted, the final ability of athletes in rubber group is faster than the final ability of athletes in Dumbbell group $1 \mathrm{~kg}$, so it can be concluded that rubber training has a greater effect than in training using a $1 \mathrm{~kg}$ Dumbbell on the speed of blows Oi tsuki Chudan in the male karate athlete of the Wadokai Dojo College Medan 11 High School in 2017.

Keywords: Rubber, Dumbbell, Oit Suki Chudan Speed

\section{A. PENDAHULUAN}

Karate dikembangkan melalui keterampilan memukul, menendang dan menangkis. Dalam hal tersebut sangat dibutuhkan power, kecepatan dan teknik yang tinggi. Maka kondisi fisik untuk atlet karate harus benar-benar baik. karena sukses dalam olahraga sering menuntut keterampilan yang sempurna dalam situasi fisik stress tinggi, maka jelaslah bahwa kondisi fisik memegang peranan yang sangat penting dalam meningkatkan prestasi atlet.

Di dalam kumite, pada buku peraturan PB.FORKI (2012 : 8) baik pukulan maupun tendangan akan mendapatkan nilai (point) sesuai dengan ketentuan yang berlaku pada sistem pertandingan karate itu sendiri, yaitu

1) Tendangan Jodan yang dimaksud Jodan adalah wajah, kepala, dan leher bagian samping dan semua teknik sesuai 6 (enam) kriteria yang dilancarkan pada lawan setelah lemparan/ bantingan atau lawan terjatuh sendiri, atau lawan tidak bertumpu lagi dikakinya memiiki point 3 (tiga)

2) Tendangan Chudan, yang dimaksud Chudan adalah perut, dada, punggung, dan sisi badan memiliki 2 (dua) point. 
3) Semua pukulan (Tsuki) yang dilancarkan di 7 (tujuh) area sasaran dan semua lecutan (Uchi) yang dilancarkan di 7 (tujuh) area sasaran memiliki 1 (satu) point.

Teknik dasar pukulan ada beberapa jenis yaitu: Gyaku-tsuki, Chudanchuki, Uraken, Sotoke, Oi-tsuki dan sebagainya. Teknik dasar tendangan antara lain: Maegeri, Mawasi, Usirogeri. Salah satu yang sering dilakukan oleh atlet karate dalam pertandingan kumite untuk memperoleh nilai (point) adalah dengan melakukan teknik Oi-tsuki Chudan (pukulan lurus kearah ulu hati). Pukulan Oitsuki Chudan ini merupakan lontaran pukulan lurus ke depan bersamaan dengan gerakan maju / mundur dengan kuda-kuda Zenkutsu-dachi. Pukulan tersebut dapat memperoleh nilai (point) apabila pukulan tersebut dilakukan dengan teknik-teknik yang benar sesuai dengan peraturan PB. FORKI (2012:8). Teknik yang benar dalam melakukan pukulan Oi-tsuki Chudan adalah tarikan tangan, putaran pinggang, jangkauan kaki, kecepatan dan daya ledak.

Untuk meningkatkan prestasi atlet, khususnya dalam cabang olahraga karate diperlukan latihan yang dapat meningkatkan seluruh komponen kondisi fisik, karena kemampuan kondisi fisik yang baik sangat menentukan tinggi rendahnya prestasi.

Dari hasil observasi pada atlet Perguruan Wadokai Dojo SMA Negeri 11 Medan penulis melihat bersama pelatih saat melakukan pukulan Oi-tsuki Chudan masih sangat mudah untuk diantisipasi oleh lawan pada saat bertanding (kumite). Karena pukulan Oi-tsuki Chudan dominan digunakan pada kumite yang harusnya membutuhkan kecepatan pukulan agar tidak diantisipasi oleh lawan sehingga bisa menghasilkan nilai (point).

Akhirnya penulis termotivasi untuk melakukan penelitian di Perguruan Wadokai Dojo SMA Negeri 11 Medan, untuk mengetahui faktor apa saja yang mendukung dalam pelaksanaan pukulan Oi-tsuki Chudan. Pukulan Oi-tsuki chudan sudah benar dilakukan namun kecepatan pukulan perlu ditingkatkan, karena dalam kumite dituntut dapat memukul dengan tenaga dan kecepatan maksimal supaya lawan sulit mengantisipasi serangan yang akan dilakukan. 


\section{B. KAJIAN TEORITIS}

\section{Hakekat Pukulan Oi-tsuki Chudan}

Dalam olahraga karate, teknik pukulan sama pentingnya dengan teknik tendangan. Pukulan dominan digunakan pada kumite yang membutuhkan kecepatan dan ketepatan. Ada banyak teknik pukulan yang dipelajari dalam karate, menurut Sujoto (1996:55) : “Gyaku-tsuki, Oi-tsuki, Jodan-tsuki, Gedantsuki, Ago-uchi dan sebagainya".

Dari beberapa teknik pukulan, namun pukulan Oi-tsuki Chudan yang menjadi objek penelitian. Seorang karateka akan memperoleh nilai (point) dalam suatu pertandingan manakala menggunakan teknik-teknik yang baku dan bentuk yang benar serta mengenai daerah sasaran yang sesuai dengan peraturan karate.

Menurut Paul Perry (1994: 83) pukulan Oi-tsuki Chudan adalah pukulan ke arah ulu hati (Chudan) diawali dari posisi gedan barai kiri, siap untuk gerakan dasar ke depan dari oi-tsuki, kemudian kedua kaki di tarik secara bersamaan pinggul dan lutut di kendurkan, kemudian otot tungkai kiri yang menjadi tumpuan berat badan secara otomatis mendorong badan ke depan, kemudian melakukan pukulan dengan memperhatikan kaki belakang. Posisi kaki belakang setelah melakukan pukulan telah berputar sedikit keluar membentuk sudut yang berguna untuk menstabilkan kuda-kuda terhadap benturan.

Kebanyakan karateka dalam pertandingan saat akan melakukan pukulan Oi-tsuki Chudan tidak melakukan tahapan memukul seperti yang ditentukan sehingga tidak menghasilkan nilai (point). Kemudian tidak tertutup kemungkinan seorang karateka akan melakukan pelanggaran yang akan mencederai lawan seperti terjadi kontak pukulan ke arah muka dan pukulan keras sehingga mencederai lawan, dan akan diberikan hukuman oleh wasit yang memimpin pertandingan tersebut. Dan kalau masih mengulangi pelanggaran yang sama akan di keluarkan dari lapangan pertandingan.

\section{Hakikat Latihan}

"Latihan adalah proses secara sistematis berlatih atau bekerja yang dilakukan secara berulang-ulang dengan kian hari kian menambah jumlah beban 
latihan”(Harsono, 1998 : 110). Sedangkan menurut Imran Akhmad (2013:2) bahwa " latihan adalah proses yang dilakukan secara sistematik dan berkelanjutan dengan menambah jumah beban untuk meningkatkan kinerja olahragawan dalam mencapai sasaran yang telah ditentukan.”

Berdasarkan pendapat diatas dapat disimpulkan bahwa latihan adalah cara yang sistematis dan terencana untuk berfungsi sebagai alat menyajikan program latihan untuk meningkatkan fungsi fisilogis, psikologis dan keterampilan gerak.

Gerakan yang baik merupakan suatu sistem yang terorganisir dengan baik, yang merupakan sumbangan dari komponen-komponen yang ada pada diri seseorang. Sajoto ( 1988:153) mengemukakan kalau kondisi fisik baik maka :

1) Akan ada peningkatan dalam kemampuan sistem sirkulasi dan kerja jantung

2) Akan ada peningkatan dalam kekuatan, kelentukan, stamina dan kecepatan

3) Akan ada ekonomi gerak yang lebih baik pada waktu latihan

4) Akan ada pemulihan lebih cepat dalam organ-organ tubuh setelah latihan

5) Akan ada respon yang lebih cepat dari organisme tubuh kita

Dalam penelitian ini bertujuan bagaimana suatu metode latihan dirancang untuk meningkatkan kecepatan pukulan Oi-tsuki Chudan dapat meningkat akibat adanya suatu latihan sehingga di harapkan terjadi peningkatan prestasi pada saat kumite.

\section{Hakekat Latihan Plyometrics}

Menurut Farentinos ( 1985:3 ) menyatakan bahwa " plyometrics berasal dari bahasa Yunani ( Greck ), Pleyheyne atau Plio dan Metric yang artinya perasaan atau pengertian yang dapat diukur (more and measure, respectively)".

Menurut Donal A Chu (2000:81) bahwa "plyometrics merupakan latihan khusus yang melatih otot-otot untuk meningkatkan kekuatan maksimum dengan lebih cepat”. Sedangkan menurut Bompa (1994:19) bahwa" plyometrics adalah salah satu latihan yang memiliki ciri khusus yaitu kontraksi otot yang kuat sehingga merupakan respon daripada pembebanan dinamik atau rangsangan yang cepat dari otot-otot".

Jika dapat disimpulkan bahwa latihan Plyometrics adalah metode yang lebih mengarah kepada pengembangan power yang gunanya untuk meningkatkan 
kekuatan, kecepatan. Dan kesimpulan ini juga yang diperkuat oleh pendapat A Chu (200:81) yang menyatakan bahwa " latihan Plyometrics akan membuat anda lebih kuat dan cepat".

Konsep latihan plyometrics menurut Harsono (1988:27) bahwa "cara yang paling baik untuk mengembangkan power maksimal pada kelompot otot tertentu ialah dengan meregangkan (memanjangkan) dahulu otot tersebut sebelum mengkontraksikan (memendekkan) otot-otot tersebut secara eksplosive (meledakledak), dengan kata lain dapat menggerakkan otot tersebut ke arah yang berlawanan".

Lebih jelasnya Harsono (1988:28) juga menambahkan “ hal penting dalam melakukan latihan plyometrics ialah : 1). gerakan harus dilakukan secara eksplosive. 2) prinsip overload (beban lebih) dan intensitasnya harus diterapkan untuk menjamin perkembangan power".

Menurut Yusup (2000:74) bahwa "otot-otot yang berfungsi dalam gerakan untuk lengan adalah antara lain, Tricep (long head), Lateral head, Medial head dan Anconeus.

\subsubsection{Hakekat Latihan Karet}

Pada dasarnya hasil kekuatan dan kecepatan, seperti yang dinyatakan oleh Sajoto (1988: 55) mengemukakan “Daya ledak atau power adalah kemampuan untuk melakukan gerakan secara eksplosif, (power=strengt x speed)".

Dengan demikian dapat disimpulkan bahwa daya ledak adalah usaha yang dilakukan secara maksimal dalam waktu yang sesingkat-singkatnya yang merupakan perpaduan antara unsur kekuatan dan kecepatan dalam mengatasi pada ruang atau jarak tertentu. Ini berarti bahwa kekuatan tetap merupakan dasar untuk pembentukan power.

Maka dari itu sebelum melakukan latihan power, seseorang harus memiliki kekuatan yang baik. hampir setiap cabang olahraga memerlukan kekuatan otot lengan maka dari itu power sangat penting dan diperlukan dalam meningkatkan kemampuan atlet. Dalam hal ini kita harus menyadari dan mengetahui bahwa dalam mencapai komponen power harus di sesuaikan dengan cabang olahraga, 
karena setiap cabang olahraga mempunyai ciri khas tersendiri yang berbeda satu dengan yang lainnya.

Kemampuan otot lengan di pengaruhi oleh daya ledak otot lengan, baik pergelangan tangan dan bahu. Jika ingin meningkatkan dan mengembangkan kekuatan yang lebih baik untuk daya ledak otot lengan, kualitas kecepatan juga harus di perhatikan.

Dalam olahraga karate pada pukulan Oi-tsuki Chudan, bahwa salah satu faktor dominan adalah daya ledak otot lengan. Dengan demikian daya ledak sangatlah di perlukan dalam pukulan Oi-tsuki Chudan sehingga terjadi peningkatan kecepatan maksimal.

Latihan yang dimodifikasi menggunakan karet sangatlah efektif dan mudah dilakukan, sehingga jika sering dilatih dengan mengikat karet ke tiang atau tembok yang menahan karet kemudian karet yang sudah di ikat di pegang atau di gengam, lakukan pukulan Oi-tsuki Chudan 10 hingga 20 kali pukulan tiap set.

\subsubsection{Hakikat Latihan Dumbbell $1 \mathrm{~kg}$}

Latihan Dumbbell $1 \mathrm{Kg}$ juga merupakan salah satu bentuk latihan plyometrics dan latihan ini dilakukan untuk menghasilkan power otot lengan, sehingga dapat meningkatkan suatu prestasi. Untuk memperoleh power, seseorang harus sudah memiliki suatu tingkat kekuatan otot yang baik. Untuk mendapatkan power haruslah di sesuaikan dengan kebuthan cabang olahraga, karate cabang olahraga mempunyai ciri khas tersendiri yang berbeda satu dengan yang lain.

Untuk mengembangkan kemampuan otot lengan haruslah melalui bentuk latihan yang menunjang kualitas otot lengan. Kemampuan power pukulan dibutuhkan pada saat memukul pada sasaran yang telah di tentukan secepat dan sekuat mungkin.

Pada dasarnya latihan Dumbbell $1 \mathrm{Kg}$ dilakukan untuk meningkatkan power otot lengan. Otot lengan memegang peranan penting dalam meningkatkan kualitas pukulan seseorang. Power otot lengan sangat dibutuhkan untuk kemampuan pukulan Oi-tsuku Chudan atlet karate. Oleh karena itu dibutuhkan suatu bentuk latihan untuk power otot lengan. 
"Menurut Farentinus (1992:16) latihan Dumbbell di lakukan dengan cara badan agak jongkok tangan masing-masing memegang dumbbell yang beratnya 10-40 pound, ayunkan ke depan dan belakang seperti kita sedang lari yang dilakukan tiap setnya 20-30 kali ayunan.

\section{METODE PENELITIAN}

Metode yang digunakan dalam penelitian ini adalah metode eksperimen. Adapun yang menjadi variabel - variabel dalam penelitian ini adalah variabel bebas dan terikat. Penelitian ini mempunyai 2 (dua) variabel bebas (perlakuan) yakni, latihan menggunakan Karet dan Dumbbell $1 \mathrm{Kg}$ serta 1 (satu) variabel terikat yaitu kecepatan pukulan $O i-t s u k i$ Chudan.

Tabel 3.2. Desain Penelitian Pre - test and Post - test Two Group Design

\begin{tabular}{llll}
\hline Pre - test & \multicolumn{1}{c}{ Matching by } & Perlakuan & Post - \\
& pairing & & Test \\
& KelompokA & Karet & T2 \\
\hline T1 & Kelompok B & Dumbbell $1 \mathrm{Kg}$ & \\
&
\end{tabular}

Keterangan T1: Test awal T2: Test akhir

\section{HASIL PENELITIAN}

Hasil penelitian menunjukkan bahwa ada pengaruh latihan karet dengan latihan menggunakan dumbbell $1 \mathrm{~kg}$ terhadap kecepatan pukulan Oi tsuki Chudan pada atlet karate putra Perguruan Wadokai Dojo SMA Negeri 11 Medan. Hal ini terlihat dari perbedaan hasil kecepatan pukulan antara kelompok karet dengan kelompok Dumbell 1kg. Penggunaan model latihan menggunakan karet bertujuan unutk membantu melatih pukulan Oi tsuki Chudan dimana saat melakukan latihan karet saat memukul karet memberikan beban dan saat pukulan dilakukan karet tersebut langsung memberikan reaksi menarik tangan kembali ke posisi siap (kumite) dengan cepat. Hasil Pre-test kecepatan pukulan kelompok karet dengan kelompok Dumbbell $1 \mathrm{~kg}$ sebelumnya telah diketahui memiliki kemampuan awalnya yaitu 0,45 untuk kelompok karet dan 0,47 untuk kelompok Dumbbell $1 \mathrm{~kg}$ dengan kriteria pengujiannya adalah $\mathrm{h}_{0}$ jika $-t_{1-\frac{1}{2} \alpha}<t<t_{1-\frac{1}{2} \alpha}$ 
$2,05<0,541<2,05)$. Karena $t_{\text {hitung }}$ jatuh pada daerah $h_{o}$ maka $h_{o}$ diterima yaitu kemampuan awal atlet pada kelompok karet sama dengan kemampuan awal atlet kelompok dummbell.

Berdasarkan analisis uji hipotesis 1 diperoleh bahwa $t_{\text {hitung }}>t_{\text {tabel }}$ $(5,21>1,70)$, maka hipotesis $\mathrm{H}_{\mathrm{o}}$ ditolak dan $\mathrm{H}_{\mathrm{a}}$ diterima. Ada pengaruh latihan menggunakan Karet terhadap kecepatan pukulan Oi-tsuki chudan pada atlet karate putra Perguruan Wadokaidojo balige kabupaten Toba Samosir tahun 2015. Berdasarkan analisisuji hipotesis 2 diperoleh bahwa $t_{\text {hitung }}>t_{\text {tabel }}(4,51>1,70)$, maka hipotesis $\mathrm{H}_{\mathrm{o}}$ ditolak dan $\mathrm{H}_{\mathrm{a}}$ diterima. Ada pengaruh latihan menggunakan Dumbbell $1 \mathrm{~kg}$ terhadap kecepatan pukulan Oi-tsuki chudan pada atlet karate putra Perguruan Wadokai dojo SMA Negeri 11 Medan tahun 2017.

Berdasarkan analisisuji hipotesis 3, dapat disimpulkan bahwa nilai ratarata Post-test untuk kelompok latihan karet lebih tinggi daripada kelompok latihan Dumbbell $1 \mathrm{~kg}$. Kriteria pengujian untuk data Post-test diperoleh $\mathrm{t}_{\text {hitung }}>\mathrm{t}_{\text {tabel }}$ yaitu 1,90>1,70 artinya Ho ditolak dan Ha diterima maka kemampuan akhir atlet kelompok karet lebih cepat dibandingkan kemampuan akhir atlet kelompok Dumbbell $1 \mathrm{~kg}$, sehingga dapat disimpulkan ada pengaruh latihan karet dengan latihan menggunakan Dumbbell $1 \mathrm{~kg}$ terhadap kecepatan pukulan Oi tsuki Chudan pada atlet karate putra Perguruan Wadokai Dojo SMA Negeri 11 Medan tahun 2017.

Teknik pukulan Oi-tsuki Chudan merupakan rangkaian gerak dinamis dan kompleks. Dimana pelaksanaanya dibutuhkan kemampuan fisik, salah satunya diantara power otot lengan yang di perlukan untuk memperoleh hasil pukulan $\mathrm{Oi}$ tsuki Chudan sebaik mungkin. Semakin baik power otot lengan dan semakin cepat reaksi tangan maka akan baik pula kualitas pukulannya. Untuk mencapai suatu prestasi maksimal, proses latihan harus teratur dan terprogram latihan fisik, latihan teknik dan latihan mental harus seirama. Pukulan Oi-tsuki Chudan digunakan pada saat kumite (pertarungan).

Dalam melakukan pukulan faktor yang dominan adalah tangan, untuk itu di perlukan power otot lengan dan kecepatan. Untuk mendukung teknik pukulan 
Oi-tsuki Chudan harus dilatih kondisi fisik terutama power dan kecepatan supaya serangan atau pukulan yang dilakukan sulit di antisipasi lawan. Untuk mendapatkan power tersebut dapat di lakukan dengan latihan Menggunakan Karetdan dumbbell $1 \mathrm{Kg}$ yang di lakukan secara berulang-ulang akan memberian renspon fisiologis yang positif kepada otot lengan dan akan beradaptasi untuk menerima beban yang akan di berikan. Latihan Menggunakan Karet adalah latihan mengunakan karet yang di ikat ke tiang atau tembok sebagai tumpuan, kemudian orang mengengam ujung karet dan melakukan pukulan ke arah depan atau membelakangi tiang atu tembok sebagai titik tumpuan tersebut. Dalam latihan menggunakan karet, karet yang digunakan memiliki lebar $2 \mathrm{~cm}$ dan panjangnya 2 cm. Sedangkan latihan Dumbbell $1 \mathrm{Kg}$ dilakukan dengan memegang di kedua tangan dumbbell seberat $1 \mathrm{Kg}$, kemudian orang melakukan pukulan yang ditentukan setiap setnya. Dari kedua bentuk latihan menggunakan Karet lebih dominan dalam meningkatkan power otot lengan. Dengan demikian otot lengan akan semakin kuat dan cepat, sehingga kemampuan dalam melakukan pukulan akan meningkat. Walau latihan ini memberikan pengaruh berarti terhadap kemampuan pukulan Oi-tsuki Chudan, akan tetapi bila dikaji dan di teliti dengan seksama mungkinkan ditemukan perbedaaan pengaruh diantara kedua bentuk latihan tersebut terhadap kecepatan pukulan Oi-tsuki Chudan.

Berdasarkan analisis gerak di tinjau pelaksaanaanya bahwasannya latihan Menggunakan Karet secara signitifikan lebih besar pengaruhnya di bandingkan dengan Dumbbell 1 Kgterhadap kecepatan pukulan Oi-tsuki Chudan pada atlet karateka dojo SMA Negeri 11 Medan tahun 2017. Karena latihan Menggunakan Karetmemiliki beban yang berat sehingga latihan ini bisa menghasilkan otot lengan dan dorongan dan tarikan tangan saat memukul lebih terlatih selanjutnya meningkatkan power dan kecepatan pukulan. Sedangkan dumbbell $1 \mathrm{Kg}$ bebanya lebih ringan karena di lakukan dengan memegang dua tangan memegang dengan beban yang ringan sehingga efektifitas lebih rendah, yang akhirnya lebih sedikit memberikan pengaruh terhadap peningkatan kecepatan pukulan Oi-tsuki Chudan.

Melihat proses pelaksanaan penelitian secara keseluruhan, peneliti menemukan berbagai kekurangan dalam pelaksanaannya yang membuat ketidak 
maksimalan pada hasil penelitian antara lain: keseriusan atlet dalam melakukan latihan dan rendahnya motivasi atlet saat berlatih.

\section{E. KESIMPULAN}

Kesimpulan yang diperoleh antara lain: Ada pengaruh yang signifikan latihan menggunakan Karet terhadap kecepatan pukulan Oi-tsuki Chudan pada atlet karate Perguruan Wadokai Dojo SMA Negeri 11 Medan terlihat dari hasil pretes atlet yaitu 0,45 dan postes yaitu 0,29 . Ada pengaruh yang signifikan latihan menggunakan Dumbbell $1 \mathrm{Kg}$ terhadap kecepatan pukulan Oi-tsuki Chudan pada atlet karate Perguruan Wadokai Dojo SMA Negeri 11 Medan terlihat dari hasil pretes atlet yaitu 0,47 dan postes yaitu 0,33. Dari hasil penelitian didapat bahwa latihan karet lebih besar pengaruhnya daripada latihan mengunakan dumbbell $1 \mathrm{~kg}$, terlihat dari hasil uji t diperoleh bahwa ada perbedaan pengaruh latihan karet dengan latihan mneggunakan Dumbbell $1 \mathrm{~kg}$ terhadap kecepaan oi tsuki chudan pada Atlet Karate Putra Perguruan Wadokai Dojo SMA Negeri 11 Medan Tahun 2017.

\section{DAFTAR PUSTAKA}

A. Chu. 1985. Jumping in to Plyometrics. Champaign. 1llionis: Leise Press.

Akhmad, Imran. 2013. Dasar-Dasar Melatih Fisik Olahragawan. Medan: Unimed Press.

Bompa, Tudor. 1994. Theory and Methodology of Training. Dubuque, IOWA: kendal/Hunt Publishing Company.

Harsono. 1988. Choaching dan Aspek-Aspek Psikologi Dalam Choaching. Jakarta: C.V. Tambak Kusuma.

Hatmisari, Dwi. 2005. Penetapan Parameter Tes Pada Pusat Pendidikan dan Pelatihan Pelajar dan sekolah Khusus Olahragawan. Jakarta: Asisten Deputi sumber daya manusia keolahragaan deputi peningkatan prestasi dan iptek olahraga kementerian negara pemuda dan olahraga kementerian Republik Indonesia.

Perry, Perry. 1994. Bebas Cidera Karate. Jakarta: Perpustakaan Nasional: Katalog dalam terbitan (KDT). 
Pengprov, FORKI. 2012. Buku Peraturan Pertandingan Karate. Medan

Radcliffe J.C dan Farentinous. 1985. Plyometrics: Explosive Power Training.Champaign. Lllionis: Human Kinetics Pubhishers.

Sujoto.J.B. 2002. Teknik Oyama Karate Seri Kihon. Jakarta: PT. Elex Media Komputindo.

Sajoto. 1998. Pembinaan kondisi Dalam Olahraga. Jakarta: Departemen Pendidikan dan Kebudayaan.

Sudjana. 2005. Metoda Statistika. Bandung: Tarsito.

Ucup, Yusup 2000. Anatomi Fungsional. Jakarta: Departemen Pendidikan dan kebudayaan. 


\section{GAYA SELINGKUNG}

1. Jurnal Halaman Olahraga Nusantara menerbitkan karya ilmiah dan hasil penelitian dalam seluruh kajian ilmu keolahragaan, baik pendidikan, kepelatihan, dan lainya dalam pengembangan teori dan konsep yang belum pernah dipublikasikan. Jurnal ini memuat (1) kumpulan informasi baru, (2) hasil objektif dari suatu kajian ilmu keolahragaan, dan (3) rekomendasi.

2. Penulisan naskah menggunakan bahasa Indonesia secara benar. Panjang naskah antara 7-20 halaman, kertas ukuran quarto, diketik 1,5 spasi, tipe huruf Times New Roman, ukuran huruf 12, margin atas dan kiri 4 cm, kanan dan bawah $3 \mathrm{~cm}$.

3. Naskah ditulis dengan sistematika dan ketentuan sebagai berikut.

a. Judul: ditulis dengan singkat, padat, terdiri dari 5-15 kata, dan menggunakan bahasa Indonesia, harus mencerminkan substansi keilmuan yang diuraikan pada batang tubuh artikel. Judul utama (main title) dan anak judul (subtitle) dipisahkan dengan dua titik. Judul artikel dicetak 15 mm dibawah tepi atas, dengan huruf capital-kecil tebal. Judul subbab peringkat 1 dicetak capital semua, rata tepi kiri, tebal, peringkat 2 dicetak capital kecil, rata tepi kiri, tebal; peringkat 3 dicetak kapital-kecil, rata tepi kiri, miring-tebal.

b. Nama penulis: Nama penulis artikel ditulis tanpa disertai gelar akademik atau gelar apapun. Nama lengkap dengan gelar akademik boleh ditulis disebelah bawah halaman pertama artikel. Nama lembaga tempat bekerja penulis juga dibuat sebagai catatan kaki dihalaman pertama. Jika lebih dari tiga penulis, hanya penulis utama saja yang dicantumkan dibawah judul; nama penulis lain ditulis dalam catatan kaki.

c. Abstrak artikel kajian ilmiah/ konseptual adalah ringkasan dari isi artikel yang dituangkan secara padat menggunakan bahasa Indonesia dan bahasa inggris. Abstrak hasil penelitian memuat masalah atau tujuan, metode, dan hasil penelitian. Abstrak terdiri dari 100-300 kata yang disusun dalam satu 
paragraph dengan format esei bukan enumeratif, dan diketik dengan spasi tunggal serta dengan format yang lebih sempit dari teks utama.

d. Kata Kunci terdiri dari 3-5 kata, yaitu istilah-istilah yang mewakili ide atau konsep dasar yang dibahas dalam penulisan karya ilmiah. Kata kunci lazimnya berupa kata dasar atau kata yang berdiri sendiri (tunggal) bukan rangkaian kata.

e. Naskah hasil penulisan ditulis dengan urutan (1) judul, (2) nama penulis, (3) abstrak, (4) kata kunci, (5) bagian pendahuluan yang harus di akhiri dengan rumusan singkat (1-2 kalimat) tentang hal-hal pokok yang akan dibahas dan tujuan dari pembahasan. Untuk artikel hasil penelitian berisi (a) rumusan masalah, (b) tujuan, dan (c) deskripsi singkat mengenai kerangka pemikiran dalam pendahuluan, (6) isi memuat (a) metode penelitian, (b) hasil penelitian, dan (c) pembahasan. (8) simpulan dan saran, (9) daftar pustaka.

f. Naskah diluar hasil penelitian ditulis dengan urutan (1) judul, (2) nama penulis, (3) abstrak, (4) kata kunci, (5) pendahuluan yang memuat latar belakang dan rumusan masalah, (6) isi, (7) simpulan, dan (8) daftar pustaka.

g. Table dan gambar/ bagan di usahakan dicetak dalam satu halaman, nomor dan judul table dan gambar dicetak di atas table dengan huruf tebal. Isi dalam table dicetak dengan huruf normal (tidak tebal). Table hanya menggunakan garis horizontal (horizontal border)

h. Penulisan daftar pustaka

1) Buku ditulis dengan urutan: (a) nama akhir, (b) koma, (c) nama depan penulis, (d) titik, (e) tahun penerbitan, (f) titik, (g) judul buku dalam huruf miring, (h) titik, (i) edisi jika ada, (j) titik, (k) kota penerbitan, (l) titik dua, (m) nama penerbit, dan (n) titik.

2) Artikel ditulis dengan urutan: (a) nama akhir, (b) koma, (c) nama depan penulis, (d) titik, (e) tahun penerbitan, (f) titik, (g) tanda petik dua, (h) judul artikel, (i) titik, (j) tanda petik tutup, (k) nama jurnal dalam cetak miring, (l) volume, (m) nomor, dan (n) titik. Apabila artikel diterbitkan 
disuatu buku, tulis kata "dalam" sebelum nama editor buku tersebut, dan buku harus ditulis didalam daftar pustaka.

3) Skripsi, thesis, atau disertasi ditulis dengan urutan: (a) nama akhir, (b) koma, (c) nama depan penulis, (d) titik, (e) tahun, (f) titik, (g) judul dalam huruf miring, (h) skripsi/thesis/disertasi pada (nama perguruan tinggi yang bersangkutan), (i) nama kota, (j) titik dua, (k) tulisan "tidak diterbitkan", dan (1) titik. 